\title{
Sciendo
}

\section{Internationalization and interaction in the time of covid 19.}

\author{
AlessandroFigus \\ PhD International Institute of Management IMI-Nova (Moldova) and University of Cassino \\ and Southern Lazio (Italy) - email:a.figus@unicas.it
}

\section{Doi: $10.2478 /$ gssfj-2021-0001}

\begin{abstract}
The Covid-19 pandemic has made interdependence globally relevant. Communication channels provide us with technological advances; they can make our lives easier, but they can also bring us viruses. In this session, we aim to explore the impact of Covid-19 on relationships between states and other global actors. To what extent will the pandemic affect international relations? What role will emerging actors such as large corporations, pressure groups or multilateral organizations take on? What impact will the possible reconfiguration of global relations have on Europe, but also on the world? This article aims to analyze the consequences of Covid-19 in our societies.
\end{abstract}

Keywords:Pandemic, internationalization, international relations, Europe, globalization

\section{Introduction}

There are events in the history of the world that radically transform society the moment they happen. These events can be caused by man or by natural events, in the first case as, for example, a war or a cataclysm in the second case. Certainly, everyone connects an earthquake to a natural event, but an earthquake is not only a natural event, it is an event that can radically transform the space in which we live, it can cause an irreversible crisis. Think of all the earthquakes that Italy has suffered since 1908 with the Messina earthquake and then again, just to name a few, the earthquake in Friuli in 1976 or L'Aquila in 2009. Yet, in comparison with what is happening now with the pandemic, even those earthquakes seem less dramatic than what has been happening for a year all over the world with Covid 19.

Why this example? The answer is very simple, it lies in the fact that during the lockdown at the beginning of 2020, there were ten million unemployed in the United States in two weeks. In 2020 from the U.S. came another indication of the seriousness of the situation: the labor report reported the loss of 701 thousand employed in March 2020, with unemployment rising to 4.4 percent. The data in 2020 compared with an increase of 273 thousand recorded and February and the expected decline of 100,000. Only yesterday it had emerged that claims for unemployment benefits jumped over 6 million. To get an idea of the earthquake that the coronavirus is unleashing in the world economy, these American data are enough, right where the absence of social shock absorbers Italian and European remove any filter to the 
impact of the epidemic. Perhaps, even more than the number (10 million), the time is striking: only two weeks, the economic equivalent of an earthquake. We are not accustomed to such violent and brutal crises. Not even wars have such immediate feedback. Comparisons can be execrable, and certainly in this case they are disconcerting, but they are indispensable: the worst economic depression since 1929 (IMF), the worst humanitarian disaster since 1945 (UN) have not led to a "concentration" of crises like that of Covid 19, even references to the past can be brandished for the future: a new Marshall Plan, a new Bretton Woods, this is what this globalized world seems to be heading for. Yet, we try to think about the future, thanks also to the vaccine policy that seems to give new hope and seems to push away, even if temporarily and theoretically, the crisis, both health and economic, that has increased at the time of Covid 19 (Alberti, 2021). The pandemic has swept away the predictions, countless reflective prospective studies conducted by domestic and international organizations, public and private, on the world of the future and how globalization can affect changes in human processes.

\section{Pandemic and internationalization}

Experts are often less likely to perform thorough analyses properly at this time due to both lack of resources and a lack of time. The Global Security Strategy developed at all levels in both the EU and UN, like so many others in our environment, has warned of the possibility of a devastating global pathogen. On the other hand, any sensitive and informed person knows that we live under the threat, certain but not so immediate and therefore delayed in its treatment, from a climatic apocalypse to a sanitary one, which could devastate a planet that has become uninhabitable. Are there relationships between these factors? At the moment, the virus has a head start on how to prevent it (vaccine) and how to treat it (therapy), and many Western governments, especially European ones, have come too late to stop it. Of course, a global or local recurrence, with dire consequences, is not excluded. And that epidemiologists, virologists have multiplied like mushrooms, this is not a phenomenon of this or that country, but very generalized, widespread, globalized. Some analysts have even rushed to publish books with their - inevitably provisional - impressions of the pandemic, and although its effects are long-lasting and profound, the lockdown has become a phenomenon whose relaxation has led to exposure to a viral phenomenon of our time: the vertigo of events, the versatile interest in things, the ease of sending information and messages, especially internationally.

At the center of the system has been health, which for a moment has taken over even the economic system, and where the World Health Organization (WHO) has placed itself central concerning the financial and banking system stating that it could happen that the virus will never be extinguished, while some self-styled scientists consider it weakened. We will probably not punish or fully compensate for the other crises to come. In this context, politics has been reduced to a process instrumental 
to the health system and, for example, elections, those that have been able to take place, have been conditioned by the pandemic crisis. The short-term strategies of electoral elections do not help long-term planning (think of the non-transparent enthronement of $\mathrm{Xi}$ or Putin, for example, but also of the recent American elections that developed around the pandemic issue and the way to manage the economic crisis. Biden won on these points certainly not on the purely political issue.

By the end of 2020, and since the pandemic began in the Chinese city of Wuhan, that is, in the last days of 2019, the coronavirus or Covid-19 has already claimed the lives of more than 4 million people. Now, the big question that scientists, leaders, and citizens are asking every day revolves around the impact that the coronavirus has had and will still have on the world economy.

Fighting this pandemic has necessarily involved population confinement measures and, as a result, a slowdown in economic activity, if not paralysis in some sectors, with devastating effects on the world economy (Alberti, 2021). WHO has stated that researchers, governments, and health care providers, despite research, despite vaccines, are still in the process of understanding and clarifying many questions about the pathogen that causes Covid-19, the similarities of the disease to other similar ones, and its impact on people's health, but what remains beyond doubt is that there are mutations of the original strain whose evolution cannot be predicted with certainty, its effects on people's health, in any case, are irremediably transferred to the health of the economy for the reasons mentioned above and that, in any case, all this is not very different from similar situations developed in the past by pandemic events (Angeletti, 2008).

The impact at the international level in a world is marked by a process of widespread globalization. The virus has spread rapidly throughout the world, with a greater incidence in Europe, where it began its escalation in Italy, and then spread to the rest of the countries of the continent: Spain, France, the United Kingdom and, to a greater or lesser extent, in the rest of the countries of the continent and the United States, in short, it did not spare anyone.

What has not been lacking is certainly the process of global internationalization, and global politics has continued to go its way, regardless of the pandemic and economic crisis. Many conflicts of our time have continued to develop, either dampened or fueled: Libya, Syria, Afghanistan, Yemen, jihadism, etc., etc., although they have been ignored by news attention (as have other epidemics that do not affect the civilized world). Let us bear in mind that internationalization is an economic issue rather than a health issue and should be seen as the process of adaptation of a company, a product, or a brand, conceived and designed for a defined market or environment, to other international markets or environments, especially other nations and cultures. Sometimes this process of adaptation frightens us, even though we seek to enhance the value of the product and its international success, and the process of communication and the circulation of information becomes important. The information blackout was even used to perpetrate or announce misdeeds, such as the Israeli annexation of the West Bank. The United Nations Security Council, 
gripped by Sino-American rivalry over the genesis and management of the coronavirus, has been unable to arbitrate a global ceasefire while the pandemic runs its course. Nature continues to lash out, perhaps with a vengeance, in other areas: thus, in the cyclone that struck India and Bangladesh. Certainly, we have experienced that there is another way to live... and to die (and to suffer).

Not everything is certainly unremitting progress in humanity. Certainly, we are facing a turning point in history, in a sense the war par excellence of our Western generation, a turning point, but how deep the result of the change is risky even to say, thinkers are divided between those who speak of a refounding of the current model of society and those who warn of changes, even deep and lasting and irreversible, but not of rebirth itself. I align myself with the latter view. The virus launches its attack while we are looking elsewhere. Thus, health flaws, economic fragility, and political weakness emerge. Distracting oneself in war is the worst mistake, on a par with marching divided (De Lorenzo, Indini, 2021). In any case, it seems exaggerated to speak of revision, of amendment to the whole of our life to date, and international relations. Political analysis is often nothing more than a personal state of mind. Already erroneously foreseen with events of greater or lesser magnitude such as the fall of communism or the Arab Spring it becomes a complete change of international paradigm and all these historical events that have occurred in the past can be traced back to social alterations, such is also the pandemic, which is a phenomenon that has involved the world as a whole, conditioning its development in the transition from too much mobility of globalization to too much static Covid 19, an event that we can certainly not consider normal.

For now, the new normal cannot be like the normal of before: the days that were always the same will not return, for now. But the capitalist society centered in a progressive and global system of interaction must go on, especially because today there is a need to restore the economy, the crisis is no longer acceptable, unless the capitalist-hedonistic structure of our society based on unbridled hedonism, will be imposed (Figus, 2020). The optimist can always cling to the familiar and consoling assertion that crises also offer opportunities.

Even without having hastened or defeated these "quarantines" (see also the section specifically created by the European Council on Foreign Relations), new prophecies for the "post-Covid-19 world" are already proliferating, almost a genre in itself. Such a colossal event leads us to think big, in macro-historical terms, but so many intertwined fears hinder critical and balanced thinking and favor visceral and hasty judgment. The chaining of data and criteria means that predictions may soon be obsolete, even ridiculed.

This state of affairs leads us to think about how changeable, how recoverable our world is, the order or disorder of the world in which we have lived. From now on we can do a counterfactual exercise: what would have happened in international relations - and in personal ones - if the coronavirus had not broken out. How many personal and political projects and illusions were postponed, modified, truncated! It will be impossible to trace the causal link with the virus - to trace the chain of 
circumstances - of the events that will occur from now on. It will lay the groundwork for a reformulation of state capitalism in China, led to Donald Trump's electoral defeat in November last year and Biden's in some ways undisputed victory, who sees the Covid-19 pandemic as a tool that has reinforced the need for a renewed and progressive internationalism. Although the virus itself does not discriminate, our global economic system does, and the impact of the pandemic has been unequal across gender, race, and social class around the world. If we are to create a more just and sustainable world post-pandemic, we must urgently embrace bold ideas to transform the way the global economy operates and for whose benefit (Figus, 2020). With the covid- 19 pandemic, scenarios have opened up in which issues such as the role of governments in the economy, I am thinking for example of the Italian economy (Bellettini G., Goldstein A, 2020), and how it must start growing again through internationalization and wherein public services and redistribution become central to the political agenda, and which go beyond political ideologies and international economic models.

\section{From crisis to international renaissance}

Surely the pandemic, as a global tragic event, can reserve space for a rebirth, there has always been space for rebirth after a crisis. The international order has always taken shape within the framework of agreements, standards, and institutions that a set of states has created to regulate and guide its relationship in a given historical period. The reconstruction of the international order has been, for example, traditionally produced at the end of general wars between great powers in the field of world history. The struggle to create the whole international order has led the major states to strive for the interest of ensuring your security through a stable peace. The order exists when states develop relations between them standardized, stable, and durable, which function following a set of organizational principles that define roles and patterns of behavior for interaction between them. International orders are in fact patterns of conduct, principles, and norms that give international relations a degree of stability and predictability.

International orders can be regional or global; they can be highly or loosely institutionalized; they can be hierarchical where the distribution of power, in its structure, can finally be structured and revolve around times, be realized by someone and taken as an example by other states. be different: multipolar. The international order can be created and stabilized through the balance of forces, hegemonic imposition, or consensus, which is then the essence of politics, sometimes even economic politics. From the crisis, the international orders can change and find strength because the international order is a product of the balance of power between the great powers that compose it so that the system is not dominated by a single state.

In this order of ideas, states accumulate power, make alliances, and implement strategies to contain the emergence of a higher power that threatens to dominate 
others, here we are faced with a new extraordinary event, the pandemic and the question is whether a virus is comparable to a war that can upset the international balance. The answer in the long run, now we are inside the crisis and not outside and we would not be objective in judging, but the rebirth will be there, of this we are sure.

However, we can say that to understand the crisis it is necessary to separate the health problem from the economic one, but many consider Covid 19 as a modern war, as stated by the senator for life Liliana Segre, in an interview with Repubblica (March 8, 2021), spoke of Covid-19 as a "modern world war" and declared herself "astonished" in front of the death toll related to the coronavirus, which in Italy has exceeded 100 thousand since the beginning of the pandemic. "I am a normal person, a citizen like others. What can I say that makes sense in front of such an impressive number?", commented Segre, retracing the stages of the health emergency and underlining with amazement "the absolute inability of the world to face and defeat this invisible enemy, which changes continuously, as if it wanted to displace us, to tell us our impotence".

Even Bill Gates, the founder of Microsoft, considers Covid 19 to be a tragic event and had long ago predicted it. "It won't be a war that kills millions of people but a very contagious virus." He said this a few years ago at a conference, Ted Talk, on Ebola. "When we were kids the disaster we worried about was nuclear war. Today the biggest risk of global catastrophe is a virus. If something is going to kill 10 million people," Gates said, "in the next few decades, it's more likely to be a highly contagious virus than

a war. Not missiles but microbes. The reason is that we have invested huge amounts of money in nuclear deterrents but we have invested very little in a system that can stop an epidemic. We are not ready for the next epidemic. Let's take Ebola. The system didn't work, they didn't have epidemiology teams ready to go, the data was inaccurate. A large outbreak requires hundreds of thousands of workers. Lack of preparedness could allow the next outbreak to be more devastating than Ebola. Next time we may not be so lucky.

A virus may be coming that doesn't make us feel so bad by allowing us to take planes and trains. A virus like the Spanish flu that spreads through the airways making millions of deaths. The World Bank estimates that if there were a global flu epidemic the estimated damage would be three trillion dollars and millions and millions of deaths" (Messenger, March 13, 2020). To equate the virus with a war seems normal, but this is not the case, and this needs to be reflected upon.

The economic impact of Covid-19 in Europe has been very invasive in 2020 and still will be throughout 2021 and also with spillover for next year, will be considered in the short and long term mainly because of the decline in exports, capital flight, the collapse of tourism, collapse of remittances to South American and East European countries, and the economic contraction and unemployment caused by the restrictions imposed to control the pandemic. 
However, the complexity of this crisis, while the region is used to dealing with external shocks, lies in the fact that this is the first time it has faced so many challenges at once. One devastating factor is having a relatively elderly population, but fortunately, Europe is still very internationally connected, as is the United States, and it is certainly good to have taken relatively quick and rigorous containment measures, to have learned how to deal with economic and health shocks of the last few decades, to have taken measures to protect families and SMEs using existing social programs.

\section{The international order and the internationalization of enterprises}

The landscape in which we are confronted is indeed the international one, where the international order is characterized by its ability to influence the global balance of power and, of course, the regional meet with the same purpose in a region delimited geopolitically. Both systems are distinguished by certain components, namely mainly the set of principles and consensual norms that guide and determine the limits of action and institutional mechanisms for peaceful conflict resolution. Here there is no conflict and there is no need to find a peaceful solution, an agreement, yet it is as if we were at war, not between states but against a power above the parties, there is no need to find a peaceful solution but there is still a need to agree to find a way out, the virus is fought together, the pandemic has no boundaries, in an interactive and globalized system only internationalization creates outlets to the exit from the crisis.

If we look at the crisis as an opportunity, we can say that the Covid-19 pandemic was a confirmation of the benefits of diversification through the internationalization of companies. Those who were surprised by this pandemic, well prepared and sufficiently globalized, suffered its effects on a much smaller scale.

In the end, internationalization saves companies to some extent because in such complex scenarios and with countries taking different measures in an uncoordinated way, diversification of business and investment strategies is a necessary way out to overcome all these difficulties and try to keep the ship afloat. Similarly, the infamous increase in speed and technological leap caused by the crisis in some respects has been known. Thus, changes in business protocols have changed dramatically, now favoring remote management and negotiation, making internationalization processes considerably easier. Internationalization and the global market also lead to a new cultural reorganization, and in this, as we shall see later, institutions are involved, starting with universities, of course.

The reasons for attempting an expansion process are always varied.

Specifically, it is a strategy that seeks to increase sales volume, manage risk management, reduce production costs, and find a solution to problems or unfavorable conditions at the point of origin. Replicating a business concept and local success of a project abroad will always involve challenges, challenges, and 
difficulties that are not easy for a company that does not have a properly trained team.

However, sinning in a certain arrogance and underestimating the complexity of entering a new market is a very common mistake, especially in companies of a certain size that also have recognition in their home market. This error of judgment is even more frequent if the origin of the company is a country of greater scale or development than the reference market. We can safely say that globalized companies have suffered less from the impact of the pandemic. And the market is international there are more opportunities and this happens not only in times of crisis.

Possible strategies for entering a new market could be explained, perhaps from minor to major in terms of the degree of difficulty, as: exporting finished products or parts or components for third-party products; alternatively, taking into account the product or service in question, concluding franchising or licensing agreements or, finally, setting up companies with local teams or more robust collaboration agreements with professionals or companies in the target market.

In any case, initially, it will be essential to understand very well what our target market is, its level of local competitiveness for our products or services, its level of maturity in the sector, who our competition will be, the profile of our customers and possible barriers to entry, both commercial and regulatory that we should circumvent.

One of the first dilemmas to be resolved will be that of an adaptation versus standardization strategy. If we were in favor of the former, we would have to adapt the product or service to each of the new markets, adopting local tastes, preferences, and protocols. If we opted for standardization, we would save a lot of time and money in designing and manufacturing the product in question, with less certainty about the penetration we can have in our new target market.

Another of the most common problems remains the cross-cultural difference each country operates with its codes and very different business etiquette. Forcing home country teams into new and culturally different markets is often a controversial solution and a source of permanent friction, just as replicating a local business concept abroad involves a major challenge, internationalization at its core, even in Covid's time.

The reference market factors to be taken into account when making the decision to internationalize a business and figuring out where to start making up a broad menu that deserves a very thorough analysis, but to which we can refer the quality of the legal system (and its hostility to the private company); level of protection for foreign investment; the level of technology available; the social climate; the political situation; communications within the territory; the level of infrastructure; production costs; human resource costs; tastes and preferences; the level of inflation; foreign exchange controls; and, last but extremely important, your ethical standards.

In any case, never before has the need arisen to implement a particular strategy, designed with the particularities that each company and market presents in mind, 
but never before have the tools and knowledge necessary for internationalization been so available to all types of businesses. It is certainly time to make the most of them, not least because the Covid 19 pandemic continues to have a significant impact, not only from an economic point of view but also on a human level.

Governments and organizations face the challenge of adapting their strategy, implementing technology solutions, and implementing continuity plans to meet the needs of employees, customers, and stakeholders.

As the crisis evolves, it is essential that companies continually work to anticipate, adapt, and manage risks, as well as assess whether their strategy adequately responds to the current environment. To facilitate this complex work for companies, and there is a need to develop a structured system that looks at the new post-pandemic reality. The corporate world will need to pursue a structured program and provide international responses tailored to its needs as it adapts to the post-Covid-19 era, starting with ensuring the continuity of its business as it reacts to exploit the opportunities that the new reality brings.

But what are these new realities we're talking about, how do companies get back into international markets? It's certain that they can interact with markets through unique opportunities, as Covid-19 increased its influence in the mid-2020s and closed entire markets and supply chains, many mid-sized companies chose to scale back their international ambitions and focus more on domestic markets. Six months later, that trend has reversed. Now, more companies are shifting their sales and supply chain focus to international markets. The trend is important in isolation, but it also highlights revolutionary international opportunities for all mid-market companies.

There is research (see the Grant Thornton study, 2021) that demonstrates this, which clearly shows a renewed international appetite in the mid-market, even as the pandemic persists. More mid-market companies are now expected to increase their share of employees focused on international markets over the next 12 months and make greater use of international suppliers and subcontractors. In all but one major region (EU), the percentage of companies seeking to make these international increases exceeds those seeking to decrease them.

The question that arises is: has globalization returned?

Of course, it is coming back, and this depends a lot on China's recovery and whether it will increase the demand for natural resources and their prices. Although the immediate impact may seem considerable, the recovery could instead be accelerated when the health problem will be solved also thanks to the widespread diffusion of vaccines. Probably the only certainty about the global crisis caused by the coronavirus is that this is not a short-term problem; it could take months, and even years, before we return to something resembling normalcy. Depending on the duration and depth of the economic crisis, there will be fundamental changes in the dynamics of markets, both in consumption and production. It has become commonplace to say that the world will never be the same after this pandemic, both because of the health and economic impacts and because of the unprecedented 
public policies designed and implemented around the world to mitigate the effects of Covid-19.

Either way, we're looking at something new, where governments have been making decisions at a frantic pace, without much time to reflect or plan, in the face of complex moral decisions.

The connection between macroeconomics and public health is not obvious, making it difficult to analyze all possible scenarios, and discussions of macroeconomic policy options have largely focused on developed countries. An important question is what the recovery will look like and when it will take off.

It should be noted that the European economy remains resilient and that monetary and fiscal policies under pressure always end up working well. 2019 and 2020 were not easy years, but 2021 is also part of a tailspin, which is why the pandemic on the one hand aggravated the situation, but at the same time diverted attention to the real European economic problem, its structural crisis.

So, if we were to ask the question what are the differences between Covid-19 and other viruses, we would be tempted to analyze the impact of the coronavirus on the world economy, on the interaction at the international level on the problems related to the epidemic that forced governments to apply extraordinary measures, limiting the mobility of people, which forced the closure of public buildings, businesses, and stores. As a result, production, consumption, and tourism have been reduced in most of the affected countries. The result is a general decline in economic activity and its key figures. Today, in the face of the pandemic crisis, we see the stock market reflecting the weakening of the international economy.

In addition, oil demand has been strongly influenced by the contraction of economic activity. Estimates Public policies and government action in the face of the crisis. The action taken by European national governments in the face of the pandemic crisis is largely due to the response of governments and central banks, which took place rapidly and with far-reaching measures and fiscal stimuli. Central banks have injected liquidity into the system, large-scale asset purchases have been made and financing instruments with negative or near-zero rates are available. For their part, governments have implemented a range of measures to help individuals and businesses.

There is an ongoing international discussion about what the next phase of recovery should look like and the role that strong public action should play in increasing demand, providing replacement income, and facilitating new investment.

The decisions that governments make as concrete public policy implementations are those to get their economic engine back on track, including the combined long-term social, economic and environmental benefits they seek to achieve through their stimulus investments, will have far-reaching implications in ensuring that it can be rebuilt in a better and more robust way.

European governments must weigh many factors when developing their stimulus packages: immediate needs, local institutional capacity, market conditions, debt possibilities, and the legacy of past infrastructure investment decisions. Other 
criteria that should be weighed in stimulus interventions or investments are their potential for job creation, the time it takes for the project to get underway, and whether public funds will help mobilize private financing to continue supporting the rapid revitalization project.

If we start with the analysis of the 2008 economic crisis, we know that one of the key lessons was that the failure to implement basic market reforms or supportive policies disadvantaged many projects relative to pre-existing technologies or left them without the momentum needed to change long-standing development approaches (Figus, 2020). Technology, think for example of digitization processes, can be the trump card for rapid economic revitalization because it can be applied to any list of projects or policies proposed as part of an incentive package, from cash transfers to direct investment in new infrastructure. what is important now is job creation, taking into account that we are in a situation that is truly comparable to a post-war situation.

\section{Cultural internationalization in times of pandemic}

In conclusion, we cannot address the theme of internationalization without mentioning cultural internationalization and concerning the educational system as a whole. The internationalization of higher education, for example, is a key factor in the construction of knowledge-based societies, since it integrates the international, intercultural, or global dimension into the characteristic functions of higher education institutions, thereby seeking to improve the quality of learning opportunities and, at the same time, of development.

It is a process that is constantly evolving in response to several factors, and currently one of these is the Covid-19 pandemic. Institutions of higher education, universities, have taken several steps to adapt educational and research services to the virtual mode. Thus, the pandemic crisis has presented many challenges, but also opportunities, for advancing internationalization processes.

The main impact of the pandemic on internationalization processes is the overall decrease in student mobility, think for example of the Erasmus project. This has historically been the main strategy used, which is why the internationalization of higher education is entering a new phase: from one based primarily on "internationalization abroad" strategies to another on "internationalization at home". Therefore, it is necessary to rethink strategies for this purpose.

In this context, virtual tools and digitization play a key role, as they will allow for the promotion of online learning systems, or what some authors call "virtual mobility" between partner institutions. This is how international and intercultural learning develops

for students, without the limitations of physical mobility. This would be a relatively less expensive and non-elite form of mobility.

However, there is a need to solve the challenges associated with the digitization process of educational services, such as the limited access to technological tools of 
vulnerable families who do not have access to the digital transformation of postpandemic higher education. Internationalization thus changes higher education and evolves in response to globalization, becoming one of the most important trends in its development and transformation. It is a mechanism for various higher education institutions to improve their competitiveness, quality, and prestige. Internationalization is, of course, understood as "the expanding global process within a system of the world economy, and immersed in the diversification of its dimensions and the areas in which it is located, and which is strongly linked to the international, intercultural, and global dimension in the purpose, functions (teaching, research, and service), delivery of post-secondary education, aimed at improving the quality of education and research for all students with the contribution of the faculty. Internationalization cannot be an end in itself, it is a means to promote institutional and social goals, improve the quality of teaching and research, promote responsible citizenship and local and global problem solving Here too, it is the pandemic covid 19 crisis that has affected the development of internationalization in recent years. Higher education in the world has been transformed by the health emergency that also produced an economic crisis. This situation has affected the structure of countries and their sectors. Today, more than 200 million students around the world have stopped attending in-person classes, some are receiving virtual classes, and others have simply suspended their education. However, this situation has presented us with new challenges of access, relevance, connectivity, and cooperation. International education has been no stranger to this situation, and the system has survived thanks to digitization.

In the end, we can say that the key these days is a major adaptation, "re-signification" of concepts and adjustment to the roles that have been played in academia, and beyond.

Starting with the internationalization of the global education system, we emphasize that it is time to adapt and innovate in a world where the future of borders is uncertain, establishing other modes of interaction. For example, exploiting technologies to generate virtual exchanges of students, teachers, researchers, and administrators in which content is shared, multinational group workshops are held and consensual solutions to the challenges we face today are presented, and this should also be seen as a mutual influence between academia and the business world, identifiable in their internationalization processes. Understanding that we are connected and that problems are not just local, makes us rethink global citizenship in the solutions we provide have broader and broader implications for which we must be prepared. During the emergency, we saw that everyone was able to contribute their expertise and that it is from collaboration that progress is made in outcomes. Having empathy and understanding of the situation we live in today, contributing from the knowledge of each profession, working in multicultural environments, and collaborating on the development of science are the values that accompany us and will be the ones that guide us in the years to come. 
This is how the roles we have been playing transform, to have the world in our classroom where the teacher is the main actor in including the international component and everyone participates in building multinational teams. We are increasingly connected to global knowledge networks through technology and various interaction tools, sharing the knowledge available in each micro-curriculum. We adapt to teach the skills needed today in the changing and deeply interconnected world of today and the post- Covid era.

\section{Conclusion}

The pandemic of Covid-19 has presented businesses and the cultural world with new challenges. Entrepreneurs have had to adapt in a short time to an unpredictable situation, often placing at the center a new way of thinking and carefully following a path of internationalization after Covid, which becomes increasingly digital and oriented to the promotion of online purchases.

The crisis was deep and the internationalization process until the end of 2019 was cadenced by very precise steps with deep analysis and implementation of strategies and implementation at a local level, but immediately after the various lockdowns the scenario in which companies and the world in the general movement have changed, the approach to foreign markets have changed and above all consumer behavior has changed.

We can't think of the crisis as anything but a war, but when you come out of the war (we hope so) you have new visions, a new cultural approach, a new way of looking at things, let's think for example of how users have now become familiar with online shopping, which often represents a safer alternative to physical stores, but which were considered a mass-market and now are. Despite compliance with safety and hygiene regulations, the risk of contagion cannot be eliminated and the fear of contracting the virus conditions consumers' buying habits, but today those who buy online have also discovered the incredible advantage of a much wider variety than what can be found in stores. In every sector, from clothing to technology, and even food, anything can be found online, as if the consumer had the option of shopping at a mall the size of the world. Isn't this a post-crisis pandemic event that has revolutionized society by internationalizing it, businesses are looking to the world by expanding their range of customers?

Not to mention digital exporting. Before the pandemic, digitizing the enterprise was a need to remain competitive in one's slice of the market (Carboni G., 2021). In the post-Covid-19 era, new motivations have been added to this strong motivation, such as the advantage of responding to a new consumer need while increasing turnover. Digitization and internationalization have become central to the post-crisis transformation, as the sale of products and services abroad make it possible to reduce logistics costs and expand one's customer base, one looks to internationalization and sets up branches everywhere, offices and showrooms abroad are not as indispensable as before in the internationalization process, because 
today, thanks to adequate technological equipment, transactions take place online, as do meetings with foreign business partners. This is also reflected in the internationalization system of universities, where online delivery becomes the norm, as does the organization of international conferences and workshops at zero cost, with results that were often surprising and unthinkable before the pandemic.

Both companies and the cultural world (I am thinking of universities) have created new managerial figures to support internationalization and will continue to play their strategic role. Today, in the post- Covid 19 era, new digital skills are required, and managers must be capable not only of accompanying companies in foreign markets but also of guiding them along the path of digital exporting (Carboni G., 2021). In the end, even the pandemic has led to some positive implications, adapting to changes in global markets becomes crucial, it is the adaptability of companies that can make a difference.

\section{References}

Alberti M. (2021), Open diplomacy. La diplomaria economica aumentata al tempo del Covid 19, Rubbettino.

Angeletti L.R., Gazzaniga V. (2008), Storia, filosofia ed etica generale della medicina, Milano, Elsevier Masson.

Bellettini G., Goldstein A, (2020), L'economia italiana dopo il Covid-19. Come ricominciare a crescere?. Newton.

Carboni G. (2021), Strategie web per i mercati esteri, Hoepli, 2021.

De Lorenzo G. and Indini A. (2021), Il libro nero del coronavirus, ed. Historica, Giubilei Regnani.

Figus A. (2020), Coronavirus Covid-19, a complex issue between health, economy, politics, and communication, Geopolitical, Social Security and Freedom Journal 3 (1).

\section{Web references}

https://ec.europa.eu/eurostat/home

https://www.who.int/data/collections

https://unric.org/it/covid-19-nuovo-rapporto-sulla-situazione-delloms-2

\section{Newspapers}

Bill Gates, la previsione: «Un virus e non la guerra ucciderà milioni di persone», Messaggero del 13 March 2020)

Liliana Segre: "Il Covid è una guerra. Piango per gli anziani", Repubblica, 8 March 2021. 